\title{
Development of mechanical engineering for extractive industries as a factor of economic development of macroregion siberia
}

\author{
Oleg Repinskiy ${ }^{1}$, Maria Gubanischeva ${ }^{2}$ and Mikhail Ivanov $^{3}$ \\ ${ }^{1}$ Irkutsk National Research Technical University, 664074 Irkutsk, Russia \\ ${ }^{2}$ Tomsk State University of Architecture and Building, 634003 Tomsk, Russia \\ ${ }^{3}$ Bratsk State University, 665709 Bratsk, Russia
}

\begin{abstract}
One can consider the development of Siberia and the Far East also called macroregion Siberia as Russia's comeback to its historic movement towards the East which will give Russia sustained economic growth based on the country's entry into the global division of labor and its active position in the markets of the Asia Pacific Region. It is the region that has become the center of global economic and technological development in the 21 st century. Gaps in the country's economy should be overcome both between separate sectors of the economy and between regions. The development of Siberia and the Far East has huge potential for the development of Russia as a whole, and it will largely determine its geoeconomic prospects in the 21 st century. Such development means the introduction of new approaches to the raw materials sector, the creation of transport and energy infrastructure, as well as the development of deep processing industries, the creation of a dynamic innovation sector, improving the living standards of the population and, in general, the formation of new environment for living and people's self-actualization. Otherwise, Siberia and the Far East are doomed to be subsidized territories with low returns for the country and its inhabitants. According to the author, the development of mechanical engineering focused on the extractive industry can be one of the main factors ensuring the successful development of the economy of the macroregion Siberia and Russia.
\end{abstract}

\section{Introduction}

The strategic perspective of Russia in the XXI century is inextricably linked with the development of Siberia and the Far East. The resumption of efficient activity in the economic development of country's eastern territories, which has 400-year history will be a key to new political, economic and social achievements for Russia. The Russian economy was focused on strengthening cooperation with European countries during a political crisis and socioeconomic reforms in the 1990s and the recovery period in 1999-2008. Such tendency were observed in the export of hydrocarbons and the import of high-tech equipment, as well as consumer goods.

At the same time, the decline in the growth rates of the European economies was intensified in Russia by the financial and economic crisis of 2008-2010. At the same time, 
the economic growth of the countries of the Asia Pacific region playing the part of engine for the world economy of XXI century remained relatively high.

Russia's move to the East ensures that the country will enter a new and incredibly important development zone providing the growth of the world economy in a current century. The richest natural resources concentrated in the macroregion Siberia are Russia's basic asset, which one should use in the nearest future. It is the raw materials sector and the machinebuilding industry providing its development probably could be a core for the high-tech economy of the whole country. The chain of economic activity should provide Russia with a breakthrough into the future but not by means of profit gained from sales of raw materials but through the development of various industries around the extractive one.

The Russian economy should not focus on a closed and self-sufficient model but there is an undesirable situation when russian resource-producing companies buy modern technologies and equipment abroad depriving domestic machine-building enterprises of their orders. An opposite situation is also undesirable - when Russian innovations are not in demand within the country but being sold abroad they work for the development of other economies and return back as high-tech products. At present, the macroregion Siberia produces more than $70 \%$ of all products exported by Russia.

At the same time, the socio-economic situation in Siberia and in the Far East is significantly worse than the national average and its indicators are declining. In the late 1980s, the income of Siberians was higher compared to average Soviet citizens but in 2019 it become $23 \%$ lower than the national average.[1]. The significant deterioration of socioeconomic indicators in Siberia and in the Far East led to a large-scale migration outflow of the population to Russia's central and southern parts. From 1990 to 2020, the population of Siberia and the Far East decreased from 32.3 million to 28.0 million. (by $13.3 \%$ ) while the migration outflow amounted to 1.6 million people. [1]

The macroregion Siberia can be developed only as a whole. Transport routes, raw material processing chains, energy system, etc. cover the territories of many regions. Strategies and programs limited by the single subjects of the Russian Federation or its industries will inevitably remain aloof from these general flows. In recent years in order to solve common problems, the territories of Siberia and the Far East have formed through the mechanism of implicit, indirect participation a cross-subsidization practice. The potential of the Siberian macroregion can be most fully revealed if the territories start communicate on a base of explicit and purposeful economic and social partnership. Therefore, the government should develop a unified strategy for the development of Siberia and the Far East until 2050, which will be further specified in the industry strategies and programs. The implementation of such strategy will create necessary institutions and tools providing managing processes in the development of the macroregion as a whole and its separate territories.

\section{Research methodology}

Currently, a number of large enterprises operate in Siberia and the Far East in the field of metallurgy, petrochemistry, timber processing, aircraft, ship and machine building as well as defence enterprises. Large cities have a great potential for a new round of industrial development, since their territories contain industrial sites with transport and energy infrastructure, as well as qualified labor resources. The cities also have a well-developed social and recreational infrastructure.

Thus, one is able to create a Siberian industrial cluster based on large cities in Siberia and the Far East located along the Transsiberian Railway and the BAM (Baikal-Amur Mainline).

The industrial cluster will be based on:

- mechanical engineering enterprises producing mining, oil/gas, construction and special equipment. 
- shipbuilding enterprises providing the production of ships, oil/gas platforms and special equipment required for the development of the Arctic Shelf;

- enterprises of processing industry (oil, coal and timber processing), nonferrous metallurgy and agro industrial complex;

- machine-building and instrument-making enterprises of the military-industrial complex;

- machine-building enterprises - aircraft, ship and automobile manufacturing (military and civil purposes);

- enterprises of forestry machine-building and agricultural engineering;

- repair and service enterprises for the resource-extracting sector of the economy.

Currently, the high importance of industrial production is remaining in the developed countries of the world due its large influence on military, political, social and economic opportunities of a country. Moreover, developed countries have begun to conduct the policy of reindustrialization through returning of industrial enterprises that had been moved to Asia in the previous 10-20 years. Modern industrial enterprises ensure the economic competitiveness of a country, budget revenues, employment and demand for innovations and $\mathrm{R} \& \mathrm{D}$.

Manufacturing and mechanical engineering in Russia have been stagnating over the past 20 years. That situation has arisen due to a fact that they are not able to compete with analogous enterprises from developed countries and China. For example, the share of manufacturing and mechanical engineering in Russia's GDP was $65.4 \%$ in 1991 and only $35.5 \%$ in 2019 [2]; the share of import machinery, equipment and vehicles in 1995 was 34 $\%$ and in 2019 already $47 \%$ [2]; the level of production localization at joint ventures in the field of heavy engineering in 2019 did not exceed $23 \%$ [2]. To date a critical situation has developed in the heavy engineering sector characterized by [2]:

- reduced sales due to lack of competitiveness;

- insufficient funding;

- lack of investment in R \& D and equipment modernization;

- technology obsolescence;

- functional and moral depreciation of equipment;

- deterioration of positions in the foreign and domestic markets.

In 2018, the share of import heavy equipment ranged from 70 to $80 \%$ : metallurgical equipment - $80 \%$, drilling equipment - more than $70 \%$, heavy lifting and transport equipment and quarry excavators - approximately $70 \%$.

According to McKinsey, the Russian industry has the following characteristics 200 - labor productivity is $26 \%$ of the figure in the United States;

- compared with other countries, Russia's GDP per person employed in the economy at purchasing power parity is several times less: the United States - 6.8; Sweden - 5.6; Spain 5.1; Poland - 2.9;

- outdated production technologies and equipment predominate (40\% of Russian thermal power plants were built 40 years ago and in the United States - $28 \%$ ).

Main enterprises in the field of heavy engineering are concentrated in the Ural, Volga, and Southern Federal Districts. The share of Siberian and Far Eastern enterprises did not exceed on average $10 \%$ and $1 \%$ respectively. World experience (Australia, Canada, Norway and other countries) shows that the coordinated development of mining and processing, the mineral resource sector and high-tech engineering can form a basis for the sustainable economy in the present-day realities.

As mentioned above, the machine building and manufacturing industry in Russia were weakened by competition with developed countries. The development of natural resources of Siberia and the Far East will give the country an opportunity to restore the high-tech industrial sector. The solution of this task will require the participation of leading foreign companies (Caterpillar, Hyundai Heavy Industries, KATO Works, Komatsu Ltd, etc.). It will 
ensure not only the attraction of investment but also the transfer of technologies, business models and production culture. At the same time, the localization of machine-building industries should be developed stage by stage starting with simple assembly and moving to the production of components (up to 30-50-70\% in accordance with the experience of Norway and other countries) and then to joint research and development activities. Extraction and processing of natural raw materials in Siberia can be modern, high-tech sectors of the economy how it happened in Norway, the United States and Canada. Together with mechanical engineering, they will require the creation of a system of high-tech contractors such as engineering centers, research laboratories and service companies. One should create such conditions that multi-purpose intellectual infrastructure could develop on the basis of leading university and research centers in Siberia and the Far East so that applications for research and development do not pass to foreign competitors. The role of universities performed research and applied developments should be strengthen as a center of attraction for a whole network of innovative enterprises.

If these tasks are implemented a transition from innovative rhetoric to the formation of internal and external demand for innovative solutions will inevitably occur as well as formation of the Russian innovation sector. Innovative, high-tech economy sectors will become a driving force for implementation of a next development cycle of Siberian and Far Eastern cities - the reconstruction of Siberian industrial cluster along the Transsiberian Railway which will ensure income growth and employment of the population, the increase of tax revenues to budgets of all levels.

At the moment, Russia cannot compete in foreign markets with the United States, Japan and the EU countries in the field of machinery and equipment production (excepting some types of weapons). The development of Siberia and the Far East will lead to the formation of a significant domestic market for mining, construction and special equipment required for developing and operating of new fields as well as for transport and production infrastructure construction. The development of the Arctic region and the Arctic shelf will entail the creation of enterprises producing ships to carry liquefied gas, oil and gas platforms, auxiliary vessels and special equipment designed for oil and gas exploration, production and transportation.

Below you can see potential market volumes of equipment required.

- The depreciation of capital assets in the oil/gas and mining industry at the end of 2018 amounted to $51.2 \%$. It means that in the next 20 years mining companies will have to invest more than 6.3 trillion rubles in their modernization or $\$ 200$ billion [4]. (The value of capital assets in 2018 amounted to 22.3 trillion rubles, the share of Russian oil drilling equipment $25 \%$, mining equipment - $20 \%$, lifting and transport equipment - $25 \%$.) Between 2017 and 2019, Russia imported mining equipment worth $\$ 7.5$ billion [4].

The development of the Arctic Shelf in the future until 2040 will require the creation of oil and gas platforms, auxiliary vessels and equipment, vessels to carry liquefied gas and an icebreaking fleet (512 vessels in total). The total cost of investments will be 6.5 trillion rubles or $\$ 200$ billion [4]. In the next 20 years, the market size of road and construction equipment is estimated at 3.5 trillion rubles or $\$ 100$ billion [4]. The volume of this market in 2018 in quantitative terms increased by $29 \%$ compared to 2015 , and the share of imported products amounted to $77 \%$.

A new wave of Siberian and the Far Eastern development will become a driving force leading to the growth of manufacturing industries and mechanical engineering - the production of drilling, mining, construction and special equipment required for deposit development and operation as well as the construction of transport and production infrastructure, the development of the Arctic region and the ocean shelf [5, 6]. Mining, manufacturing and mechanical engineering will create solvent demand for qualified staff, scientific research and innovative developments. 


\section{Research results}

The market volume of oil/ gas and mining industry, road construction equipment, ships, oil and gas platforms and equipment required for development of Siberia, the Far East and the Arctic shelf in the next 20 years is estimated at $\$ 500$ billion (16-18 trillion rubles), the growth rate of this market will be 10-15\% per year. Industrial policy should ensure the production of $70-80 \%$ of required machinery and equipment at Russian enterprises, primarily at enterprises in Siberia and the Far East. It would also be advisable that the main volume of investments in the creation and development of heavy engineering be given by foreign and Russian private companies. The macroregion Siberia has all preconditions to become a base for the development of the entire country. Nevertheless, it will be much better if it happens not at the expense of profit from raw materials sales but through the development of high-tech industries. One should develop new mechanisms for the economic growth of Russia and the macroregion Siberia [7, 8]. They can be created by means of consistent economic, industrial and social policies. The implementation of projects in the extractive sector in Siberia and the Far East will become the basis for the development of mechanical engineering and other related industries in the macroregion Siberia as well as in other parts of the country. Simultaneously with the development of high-tech industrial production, the sector of innovative activity, breakthrough research and development focused on application within Russia but not for sale to other countries should be formed $[9,10,11]$.

The objective of the long-term industrial policy is to accelerate the development of extractive industries in Siberia and the Far East accompanied by the development of mechanical engineering and other related industries. The raw materials sector should ensure steady domestic demand for mining and construction equipment, oil/gas and special equipment required for the implementation of large resource extraction and infrastructure projects $[12,13]$. At the same time, along with mechanical engineering the sector of innovation, research and development should be formed. We need a policy encouraging the transfer of technologies, localization and adaptation of leading foreign companies in Russia.

\section{Discussion of the results}

Heavy engineering should become the engine of industrial high-tech development in Russia including primarily Siberia and the Far East. It will be the main customer of qualified personnel and scientific research, innovative developments. The engineering sector should be created (recreated) with the involvement of leading foreign companies - Caterpillar (USA), Hyundai Heavy Industries (South Korea), KATO Works, Komatsu Ltd (Japan), etc. This factor will ensure the attraction of investment, the transfer of technologies, business models and production culture. The production of equipment will increase in stages starting with a simple assembly and ending with the localization of various production elements - up to $30-50-70 \%$ (Norway's experience) $[14,15]$.

The intensification of further development of Siberia and the Far East provides an opportunity to restore the position of the high-tech industrial sector in the Russian economy. The development of Siberia's and the Far East's industrial potential will lead to the following positive changes.

- expand opportunities for deep processing of natural resources;

- create conditions for the formation of a high-tech economy sector;

- cause the growth of related sectors of the economy (multiplicative effects);

- allow to authorities to create new jobs whereby a population outflow from the regions will be stopped;

- strengthen the country's defense capability; 
- create conditions for the modernization of the transport, energy, and engineering infrastructure of cities and settlements.

The creation of competitive enterprises in the Siberian industrial zone will require deep technological and managerial modernization of business. One should ensure the transfer of advanced technologies and competitive business models. It will led to:

- shift to digital design of parts, mechanisms and machines using automatic design software (Intergraph, AVEVA, Bentley, SAP, Oracle, Dassault Systemes, etc.);

- mass introduction of new composite materials for design and production of parts and machines;

- modular organization of production, building of integrated technological chains, using outsourcing, etc.

The technological modernization of the industrial sector is impossible without extensive using of modern digital technologies including the development of software required for the organization of production and management of complex types of machinery and equipment. Thereby, in turn, conditions for the development of small and medium-sized businesses in the field of intellectual rights will be created.

\section{Conclusion}

The policy of economic development of Siberia and the Far East should be built within the paradigm of country's development as a whole. At the same time, financial, technological and personnel investments should lead to significant acceleration of Russia's socio-economic development in the XXI century. One should refuse from a link to administrative-territorial division and move on to large infrastructure, industrial and social projects ensuring the development of whole Siberia and the Far East.

The policy of economic development of Siberia and the Far East should be built taking into account the formation of territorial structured complexes - priority development area (PDA) which require the coordinated development of industrial, transport, energy and social infrastructure, as well as the attraction and arrangement of labor resources. An approach, which does not provide integrated development, significantly complicates the logistics and management of development processes should remain in the past. The transition to the formation of the priority development area (PDA) will allow us to refuse from a large number of poorly connected projects and ensure the implementation of several large complex projects that really determine the development of the macroregion in the XXI century.

Industrial policy should take into account the large-scale projects already being implemented on the territory of the Russian Federation and possible restrictions on transport and energy infrastructure, labor resources; ensure the fulfillment of export obligations of the Russian Federation, the filling of the budget system of the Russian Federation and employment growth.

The sector of heavy machinery and special equipment should become a driver for the development of the entire machine building industry and for associated metallurgical industries as well as a key customer for engineering services and R \& D.

Industrial policy should permit the active involvement of leading foreign companies as investors and manufacturers. It is necessary for the placement of high-tech machine-building industries followed by a phased localization of activities (starting with the screwdriver assembly and moving on to the production of components parts).

Industrial policy should ensure the deep modernization of existing and the creation of new high-tech industries, the integration of various sectors of industrial production through the transfer of technologies, business models and management systems, the transition to a modular organization of production, the building of integrated technological chains, the use of outsourcing, etc. 
Industrial policy should be coordinated with tax, customs and export policy in order to ensure the creation of conditions leading to the accelerated development of high-tech engineering sectors with the participation of the biggest foreign companies. In order to support newly created enterprises, it is necessary to provide them with a number of tax benefits including a reduction in transport tariffs, tariffs for electric and thermal energy. Customs policy should ensure the restriction of import machine-building products and stimulate the localization of such production in the country.

\section{References}

1. Russian regions: socio-economic indicators-2020: Statistical collection, https://eng.rosstat.gov.ru/

2. Federal State Statistics Service (Rosstat) Russia and the countries of the world 2020. Statistical collection, https://eng.rosstat.gov.ru/

3. Effective Russia. Productivity as the foundation for growth (McKinsey Global Institute, 2019) http://www.mckinsey. com/Insights/MGI/Research.

4. Federal State Statistics Service, http://www.gks.ru/wps/wcm/connect/ rosstat_main/rosstat/ru/statistics/enterprise/fund.

5. S. Zakharov, A. Bovkun, K. Vasiliev, Intern. Conf. Quality Man., Trans. and Inf. Sec., Inf. Techn., 32 (2017)

6. V. Konyuhov, A. Gladkih, R. Zott, A J. of Phys.: Conf. Ser., 1582 (2020)

7. A. Gladkih, V. Konyuhov, I. Galyautdinov, E. Shchadova, IOP Conf. Ser.: Mater. Sci. Eng., 760 (2020)

8. I. Galyautdinov, G. Shchadov, V. Konyukhov, O. Tomshin, IOP Conf. Ser.: Earth and Env. Sci, 408 (2020)

9. A. Basova, A. Nechaev, World Appl. Sci. J., 1544 (2013)

10. A. Nechaev, D. Ognev, O. Antipina, Intern. Conf. "Quality Man., Trans. and Inf. Sec., Inf. Techn.", 548 (2017)

11. A. Nechaev, S. Zakharov, A.Troshina, Intern. Conf. "Quality Man., Trans. and Inf. Sec., Inf. Techn.", 552 (2017)

12. S. Zakharov, A. Troshina, A. Lobova, Intern. Conf. "Quality Man., Trans. and Inf. Sec., Inf. Techn.", 601 (2017)

13. A. Dykusova, E. Golovina, IOP Conf. Ser.: Mat. Sc. And Eng., 667 (2019)

14. Y. Barykina, IOP Conf. Ser.: Mat. Sc. and Eng., 667 (2019)

15. A. Bovkun, I. Korodyuk, Conf. Ser.: Mat. Sc. and Eng., 667 (2019) 